\title{
Influence of genital herpes on results of fluorescent treponemal antibody absorption test
}

\author{
T. CHAPEL, * C. D. JEFFRIES, $\dagger$ W. J. BROWN, $\ddagger$ AND J. A. STEWART \\ From the ${ }^{*}$ Department of Dermatology and Syphilology and the + Department of Microbiology, \\ Wayne State University School of Medicine, Detroit; the $\ddagger$ Pathology Department, Hutzel Hospital, \\ Detroit; and the §Virology Division, Center for Disease Control, Atlanta
}

SUMMARY Both the fluorescent treponemal antibody absorption (FTA-ABS) test and Venereal Disease Laboratory (VDRL) test for syphilis were performed routinely on 113 men with histories of genital ulcerations. The difference in negative VDRL and borderline FTA-ABS results between patients with and without herpes simplex virus in their genital ulcers and no evidence of previous or untreated syphilis was not statistically significant. Furthermore, use of the FTA-ABS test as a confirmatory rather than as a screening test eliminates false-positive, borderline, or reactive results in patients with non-syphilitic ulcers.

\section{Introduction}

The fluorescent treponemal antibody absorption (FTA-ABS) test is highly specific and false-positive reactions are rare (Mackey et al., 1969, Goldman and Lantz, 1971). False-positive reactions occur mainly in conditions associated with increased or abnormal immunoglobulins such as autoimmune or connective tissue disease (Catterall, 1972; Tuffanelli, 1973; McKenna, et al., 1973). Borderline or false-positive results have also been reported in cases of drug addiction (Kaufman et al., 1974), smallpox vaccination (Jacobs et al., 1971), pregnancy (Drew and Sarandria, 1975), and drug-induced lupus erythematosus (Monson, 1973).

Wright et al. (1975) reported false-positive FTA-ABS results in 32 patients with genital herpes simplex virus (HSV) infection and no historical or clinical evidence of previous or untreated syphilis. All of these patients had non-reactive results to rapid plasma reagin (RPR) and Treponema pallidum haemagglutination (TPHA) tests. However, six $(18.8 \%)$ patients had reactive results to the FTA-ABS tests. Wright et al. (1975) speculated that since HSV is a DNA virus the infected host may form anti-DNA antibody. If the commercially prepared sorbent fails completely to adsorb this antibody it may attach to the DNA of the treponemes used in the FTA-ABS reaction and thus be detected by immunofluorescence.

Address for reprints: Dr T. Chapel, Department of Nermatology and Syphilology, 540 East Canfield, Detroit, Michigan 48201, USA

Received for publication 23 November 1977
Clinicians lacking access to darkfield microscopy and culture for HSV must base a diagnosis of syphilis on the clinical picture and on the results of serological tests. In such instances Duncan et al. (1974) have emphasised the use of the FTA-ABS test. However, false-positive FTA-ABS reactions in patients with genital herpes infection could lead to an incorrect diagnosis of syphilis.

This paper reports the results of the FTA-ABS test, with commercial reagents, in a group of patients with genital ulcers. Data from patients with and without genital herpes are compared and these results discussed in relationship to those published by Wright et al. (1975).

\section{Materials and methods}

\section{STUDY POPULATION}

The study was conducted at the Detroit Social Hygiene Clinic from September 1973 to March 1975. One hundred and thirteen consecutive men with penile ulcerations underwent a standardised interview and examination after written, informed consent. Of these, 13 were Caucasian and the remainder were black.

\section{MICROBIOLOGICAL STUDIES}

Secretions were collected with sterile rayon-tipped swabs and cultured for aerobic and anaerobic bacteria, mycoplasma, yeasts, and fungi, as reported by Chapel et al. (1978). Material for virological studies was scraped from the ulcer base with a sterile surgical blade, placed in virus transport 
medium, and immediately sent to the laboratory. This material was used to inoculate baby hamster kidney cells (BHK-21/13), and HSV was identified by the neutralisation technique of Tokumaru et al. (1969). In addition, ulcer secretions were examined for treponemes by darkfield microscopy.

\section{IMMUNOLOGICAL STUDIES}

Immunological studies were performed on serum obtained from patients at the initial visit and again at 10 to 14 days. Fresh sera were tested by the Venereal Disease Research Laboratory slide test (US Center for Disease Control, 1969), and the FTA-ABS test was performed by the technique of Hunter et al. (1964), and with materials, sorbent, and antigen supplied by Baltimore Biological Laboratories.

Circulating HSV antibodies were measured by the indirect haemagglutination test. The McIntyre $V R_{3}$ strain was used to prepare type 1 antigen and the MS strain for type 2 antigen, according to the methods of Stewart and Hermann (1976) and Palmer et al. (1974).

\section{Results}

A detailed report of the microbiological flora recovered from the ulcers of 100 of the 113 men has been reported by Chapel et al. (1978). HSV was cultured from the ulcers of 41 men, and three more men with herpetiform ulcers had negative culture results, but their paired sera showed a four-fold or greater rise in HSV antibody titres. This combination of clinical and serological findings supported a diagnosis of genital herpes. Of these 44 patients with genital herpes, six had concomitant gonorrhoea, six non-specific urethritis, two infection with Haemophilus ducreyi, and two infection with Treponema pallidum.

Sixty-nine men had no laboratory evidence of genital herpes, but 12 of them had primary syphilis, and three more had secondary syphilis with persisting chancres. In addition, seven men had lesions of probable traumatic origin, two had ulcerated, fixed drug reactions, and four had, respectively, primary cutaneous gonococcal infection, Group A streptococcal pyoderma infection, staphylococcal pyoderma infection, and an ulcerated Candida albicans balanitis. The cause of the ulcers in the remaining 41 men was not established. Sexually transmitted diseases unassociated with the genital ulcers were diagnosed in 20 of the 69 men. Of these 20 patients, 10 had concomitant gonorrhoea, seven non-specific urethritis, and three condyloma accuminatum.
Sera from all 113 patients were examined by the VDRL slide and FTA-ABS tests. Results to both the VDRL and the FTA-ABS tests were negative in 36 men with genital herpes and reactive in five patients with genital herpes (Table 1). An additional two men with HSV had borderline

Table 1 Results and case histories (on first visit) of eight patients with genital herpes and positive results to serological tests for syphilis

\begin{tabular}{|c|c|c|c|}
\hline \multirow[b]{2}{*}{ Case no. } & \multicolumn{2}{|c|}{ Results of serological tests } & \multirow[b]{2}{*}{ History of syphilis } \\
\hline & $V D R L$ & $F T A-A B S$ & \\
\hline $\begin{array}{l}5 \\
78 \\
43 \\
79 \\
29 \\
85 \\
4 A \\
3 \mathbf{A}\end{array}$ & $\begin{array}{l}\text { WR } \\
\text { NR } \\
\mathbf{R}(1: 4)^{*} \\
\text { NR } \\
\text { WR } \\
\text { R }(1: 4) \\
\text { NR } \\
R(1: 16)\end{array}$ & $\begin{array}{l}\mathbf{N R} \\
\mathbf{B L} \\
\mathbf{R}(+2) \dagger \\
\mathbf{R}(+1) \\
\mathbf{B L} \\
\mathbf{R}(+4) \\
\mathbf{R}(+2) \\
\mathbf{R}(+4)\end{array}$ & $\begin{array}{l}\text { None } \\
\text { None } \\
\text { Primary } \\
\text { Primary } \\
\text { Previously treated primary } \\
\text { Previously treated primary } \\
\text { Previously treated primary } \\
\text { Previously treated early } \\
\text { latent }\end{array}$ \\
\hline
\end{tabular}

WR $=$ Weakly reactive

NR = Non-reactive

$\mathrm{BL}$ - Borderline reactive

$\mathbf{R}=$ Reactive with titre (VDRL)* or degree of reaction (FTAABS)†

reactive results in the FTA-ABS test. The five patients with reactive results and one of the two with borderline results to the FTA-ABS test had histories of current or treated syphilis. Only one patient (Case 78) had borderline results to the FTA-ABS test, negative results to the VDRL test, and no evidence of untreated or treated syphilis. On repeat testing 21 days later the results of both the VDRL and FTA-ABS tests were non-reactive.

One or both serological tests for syphilis gave reactive results in 30 of the remaining 69 men without cultural or serological evidence of HSV (Table 2). Of these 30 men 24 had histories of treated or untreated syphilis. Two other men had reactive results to the VDRL test but non-reactive results to the FTA-ABS test, and four others had nonreactive results to the former and borderline results to the latter. Three of the latter four men had negative results to the serological tests when repeated, while the other defaulted. The difference in negative results and borderline results to the VDRL and FTA-ABS tests respectively between men with and without HSV in their genital ulcers and no evidence of previous or untreated syphilis was not significant when analysed by the Fisher's Exact test using the one tail test $(\mathrm{P}=\mathbf{0} \cdot 2371)$.

\section{Discussion}

Both the VDRL and FTA-ABS tests were performed routinely on each of the 113 men who participated 
Table 2 Results and pertinent histories (at first visit) of 30 patients with genital ulcers and negative results to tests for herpes simplex virus but positive results to serological tests for syphilis

\begin{tabular}{|c|c|c|c|c|}
\hline \multirow[b]{2}{*}{ Case no. } & \multicolumn{2}{|c|}{ Results of serological tests } & \multirow{2}{*}{\multicolumn{2}{|c|}{ History of syphilis }} \\
\hline & $V D R L$ & $F T A-A B S$ & & \\
\hline 24 & NR & BL & None & \\
\hline 31 & NR & BL & None & \\
\hline 42 & WR & NR & None & \\
\hline 48 & WR & NR & None & \\
\hline 59 & NR & BL & None & \\
\hline 64 & NR & BL & None & \\
\hline 32 & $R(1: 16)^{*}$ & $\mathbf{R}(+4) \dagger$ & Primary & \\
\hline 38 & $R(1: 16)$ & $\mathbf{R}(+4)$ & Primary & \\
\hline 39 & $R(1: 4)$ & $\mathbf{R}(+3)$ & Primary & \\
\hline 51 & $R(1: 32)$ & $\mathbf{R}(+2)$ & Primary & \\
\hline 52 & $\mathbf{R}(1: 2)$ & $\mathbf{R}(+1)$ & Primary & \\
\hline 57 & $R(1: 16)$ & $\mathbf{R}(+4)$ & Primary & \\
\hline 60 & $R(1: 32)$ & $\mathbf{R}(+2)$ & Primary & \\
\hline 89 & $\mathbf{R}(1: 4)$ & $\mathbf{R}(+2)$ & Primary & \\
\hline 91 & WR & $\mathbf{R}(+4)$ & Primary & \\
\hline 96 & $R(1: 8)$ & $\mathbf{R}(+4)$ & Primary & \\
\hline 99 & $\mathbf{R}(1: 2)$ & $\mathbf{R}(+3)$ & Primary & \\
\hline 13 & $\mathbf{R}(1: 128)$ & $\mathbf{R}(+4)$ & Secondary & \\
\hline 22 & $R(1: 128)$ & $R(+4)$ & Secondary & \\
\hline 66 & $R(1: 64)$ & $R(+4)$ & Secondary & \\
\hline 4 & WR & $\mathbf{R}(+1)$ & Previously treated & \\
\hline 46 & NR & $\mathbf{R}(+1)$ & Previously treated & \\
\hline 65 & $\mathbf{R}(1: 1)$ & $\mathbf{R}(+2)$ & Previously treated & \\
\hline 69 & NR & $\mathbf{R}(+1)$ & Previously treated & \\
\hline 83 & NR & $\mathbf{R}(+3)$ & Previously treated & \\
\hline 90 & NR & $R(+4)$ & Previously treated & \\
\hline 101 & NR & $\mathbf{R}(+4)$ & Previously treated & \\
\hline $9 \mathbf{A}$ & $R(1: 2)$ & $\mathbf{R}(+4)$ & Previously treated & \\
\hline 1 & $\mathbf{R}(1: 2)$ & $\mathbf{R}$ & $\begin{array}{c}\text { Previously treated } \\
\text { latent }\end{array}$ & early \\
\hline 40 & WR & $\mathbf{R}$ & $\begin{array}{l}\text { Previously treated } \\
\text { latent }\end{array}$ & early \\
\hline
\end{tabular}

WR $=$ Weakly reactive

$\mathbf{N R}=$ Non-reactive

$\mathrm{BL}=$ Borderline reactive

$\mathbf{R}=$ Reactive with titre (VDRL)* or degree of reaction (FTA ABS)†

in the study with a history of genital ulcerations. Five of the patients who had neither treated nor untreated syphilis gave borderline reactive results to the FTA-ABS test, but non-reactive results to the VDRL test, both of which tests gave negative results in the four patients who returned for follow up. These results are similar to those of Jaffe (1975), who reported that most patients with negative and borderline reactive results to the VDRL and FTA-ABS tests respectively have non-reactive results to serological tests on repeat examination. Only a small percentage of these patients had untreated syphilis.

In our patients, the difference between negative and borderline results to the VDRL and FTA-ABS tests, respectively, in men with and without HSV in their genital ulcers, and no evidence of previous or untreated syphilis, was not statistically significant. The difference between our results and those reported by Wright et al. (1975) may be due, as they suggested, to sorbent that failed to remove viral
anti-DNA antibody which then attached to the DNA of the treponemes. Indeed, Wilkinson and Ferguson (1968), and Wilkinson and Wiseman (1971), and Mackey et al. (1969) found lower false-positive results to the FTA-ABS test with a whole Reiter treponeme 'sonicate' than with the culture fluid extract 'sorbent'. The commercial sorbent (Baltimore Biological Laboratories) used in this study provided greater specificity than the commercial sorbent used by Wright et al. (1975). Previously mentioned concomitant diseases or problems with laboratory techniques as reported by Sparling (1971), Elsas (1972), Pien et al. (1976), and McKenna et al. (1973) could perhaps explain some of the false-positive results.

Burns (1975) reported a series of 56 clinically healthy persons with no history of syphilis and negative results to the VDRL test but borderline or reactive results to the FTA-ABS test. Twenty $(35.7 \%)$ of these patients spontaneously developed non-reactive results to the FTA-ABS test over a period of eight months or less. Further, Jaffe (1975) found that when the FTA-ABS test is used to screen for syphilis it gives an increased incidence of false-positive reactions. Proper use of the FTA-ABS test as a confirmatory rather than as a screening test eliminates false-positive borderline or reactive results to the FTA-ABS test in patients with nonsyphilitic genital ulcers. Nonetheless, additional reports are necessary to evaluate further any possible link between genital herpes infection and apparent false-positive reactive results to the FTA-ABS test.

This study was supported in part by Contract HSB 21-73-525 from the US Public Health Service and from the Detroit General Hospital Research Corporation.

We are grateful to Mr David Foust, senior statistician, Detroit Department of Health, who assisted in the statistical analyses.

\section{References}

Burns, R. E. (1975). Spontaneous reversion of FTA-ABS test reactions. Journal of the American Medical Association, 234, 617-618.

Catterall, R. D. (1972). Systemic disease and the biological falsepositive reaction. British Journal of Venereal Diseases, 48, 1-12.

Chapel, J., Brown, W., Jeffries, C., and Stewart, J. (1978). The microbiological flora of penile ulcerations. Journal of Infectious Diseases, 137, 50-56.

Drew, F. L., and Sarandria, J. L. (1975). False-positive FTA-ABS in pregnancy. Journal of the American Venereal Disease Association. 1, 165-166.

Duncan, W. C., Knox, J. M., and Wende, R. D. (1974). The FTA-ABS test in dark-field positive primary syphilis. Journal of the American Medical Association, 228, 859-860.

Elsas, F. J. (1972). The wandering treponeme. A possible source of error in fluorescent antibody staining of spiral forms in body fluids. British Journal of Venereal Diseases, 48, 26-28.

Goldman, J. M., and Lantz, M. A. (1971). FTA-ABS and VDRL slide test reactivity in a population of nuns. Journal of the American Medical Association, 217, 53-55. 
Hunter, E. F., Deacon, W. E., and Mayer, P. E. (1964). An improved FTA test for syphilis. The absorption procedure (FTA-ABS) Public Health Reports (Washington), 79, 410-412.

Jacobs, M. J., Protho, G. W., and Carpenter, R. L. (1971). Apparent transient false-positive FTA-ABS test following smallpox vaccination. Journal of the Oklahoma State Medical Association, 64, 372.

Jaffe, H. W. (1975). The laboratory diagnosis of syphilis: new concepts. Annals of Internal Medicine, 83, 846-850.

Kaufman, R. E., Weiss, S., Moore, J. D., Falcone, V., and Wiesner, P. J. (1974). Biological false-positive serological tests for syphilis among drug addicts. British Journal of Venereal Disease, 50 350-353.

Mackey, D. M., Price, E. V., Knox, J. M., and Scotti, A. (1969). Specificity of the FTA-ABS test for syphilis. An evaluation. Journal of the American Medical Association, 207, 1683-1685.

McKenna, C. H., Schroeter, A. L., Kierland, R. R., Stilwell, G. G., and Pien, F. D. (1973). The fluorescent treponemal antibody absorbed (FTA-ABS) test beading phenomenon in connective tissue diseases. Mayo Clinic Proceedings, 48, 545-548.

Monson, R. A. M. (1973). Biologic false-positive FTA-ABS test in drug-induced lupus erythematosus. Journal of the American Medical Association, 224, 1028-1030.

Palmer, D. F., Cavallaro, J. J., Hermann, K. L., Stewart, J. A., and Walls, K. W. (1974). A Procedural Guide to the Serodiagnosis of Toxoplasmosis, Rubella, Cytomegalic Inclusion Disease, Herpes Simplex. Immunology series No. 5, pp. 23-56. United States Center for Disease Control: Atlanta.

Pien, F. D., Markowitz, H., McKenna, C. H., and Schroeter, A. L. (1976). Problems with beaded fluorescence pattern in FTA-ABS test. Journal of the American Venereal Disease Association, 3, 20-24.
Sparling, P. F. (1971). Diagnosis and treatment of syphilis. New England Journal of Medicine, 284, 642-653.

Stewart, J. A., and Hermann, K. L. (1976). Herpes simplex virus. In Manual of Clinical Immunology. pp. 416-420. Edited by N. R. Rose and H. Friedman. American Society for Microbiology: Washington, D.C.

Tokumaru, T. (1969). Herpes virus. In Diagnostic Procedures for Viral and Rickettsial Infections, fourth edition, pp. 641-700. Edited by E. H. Lennette and N. J. Schmidt. American Public Health Association: New York.

Tuffanelli, D. L. (1973). Normal individuals with chronic falsepositive (CFP) tests for syphilis. In Sexually Transmitted Diseases. pp. 95-104. Edited by L. Nicholas. Thomas: Springfield, Illinois.

United States Center for Disease Control (1969). Manual of Tests for syphilis. Publication No. 411. p. 15. US Department of Health Education and Welfare, Public Health Service. US Government Printing Office: Washington, D.C.

Wilkinson, A. E., and Ferguson, H. G. (1968). Some observations on the sorbing agent used in the absorbed fluorescent treponemal antibody (FTA-ABS) test. British Journal of Venereal Diseases, 44, 291-294.

Wilkinson, A. E., and Wiseman, C. C. (1971). The role of sorbent in the absorbed fluorescent treponemal antibody (FTA-ABS) test. Proceedings of the Royal Society of Medicine, 64, 422-425.

Wright, J. T., Crumer, A. W., Ridgway, G. L. (1975). False positive FTA-ABS results in patients with genital herpes. British Journal of Venereal Diseases, 51, 329-330. 